\title{
Limited by Health
}

National Cancer Institute

\section{Source}

National Cancer Institute. Limited by Health. NCI Thesaurus. Code C110971.

An indication that a person's activities are limited by their health condition. 